\title{
Protein kinase A type I activates a CRE-element more efficiently than protein kinase A type II regardless of $C$ subunit isoform
}

\author{
Øystein Stakkestad ${ }^{1,3}$, Anja CV Larsen ${ }^{1,2}$, Anne-Katrine Kvissel ${ }^{1,2}$, Sissel Eikvar ${ }^{1,2}$, Sigurd Ørstavik ${ }^{1,4}$, \\ Bjørn S Skålhegg ${ }^{1 *}$
}

\begin{abstract}
Background: Protein kinase A type I (PKAI) and PKAll are expressed in most of the eukaryotic cells examined. PKA is a major receptor for CAMP and specificity is achieved partly through tissue-dependent expression and subcellular localization of subunits with different biochemical properties. In addition posttranslational modifications help fine tune PKA activity, distribution and interaction in the cell. In spite of this the functional significance of two forms of PKA in one cell has not been fully determined. Here we have tested the ability of PKAI and PKAll formed by expression of the regulatory (R) subunits Rl $\alpha$ or Rll $\alpha$ in conjunction with $C \alpha 1$ or $C \beta 2$ to activate a co-transfected luciferace reporter gene, controlled by the cyclic AMP responsive element-binding protein (CREB) in vivo.
\end{abstract}

Results: We show that PKAI when expressed at equal levels as PKAll was significantly $(p<0.01)$ more efficient in inducing Cre-luciferace activity at saturating concentrations of CAMP. This result was obtained regardless of catalytic subunit identity.

Conclusion: We suggest that differential effects of PKAI and PKAll in inducing Cre-luciferace activity depend on R and not $\mathrm{C}$ subunit identity.

\section{Background}

Cyclic 3', 5'-adenosine monophosphate (cAMP) is a key intracellular signaling molecule, which main function is to activate the cAMP-dependent protein kinases (PKA) $[1,2]$. PKA is a heterotetrameric holoenzyme composed of two regulatory $(\mathrm{R})$ and two catalytic $(\mathrm{C})$ subunits, which is enzymatically inactive in the absence of cAMP. When two molecules of cAMP bind to each of the $\mathrm{R}$ subunits [3], the $C$ subunits are released and activated to phosphorylate serine and threonine residues on specific intracellular target proteins $[4,5]$. Several PKA substrates have been identified of which the synthetic peptide Kemptide [6] and the naturally occurring substrate cAMP responsive element binding protein (CREB) are of the best characterized $[7,8]$. In primates, four genes encoding the $\mathrm{R}$ subunit and four genes encoding the $\mathrm{C}$ subunit, have been identified and designated RI $\alpha$,

\footnotetext{
* Correspondence: b.s.skalhegg@medisin.uio.no

'Department of Nutrition, Institute for Basic Medical Sciences, University of

Oslo, Sognsvannsveien 9, P.O. Box 1046 Blindern, N- 0316 OSLO, Norway

Full list of author information is available at the end of the article
}

RI $\beta$, RII $\alpha$, RII $\beta$ and $C \alpha, C \beta, C \gamma$ and X-chromosome encoded protein kinase $\mathrm{X}$ (PrKX) [9].

Whereas no splice variants for RI $\beta$ and RII $\beta$ have been described, RI $\alpha$ is transcribed from at least two different promoters. The first exons of the RI $\alpha$ gene, exon 1a and $1 \mathrm{~b}$, give rise to alternatively spliced but identical proteins RI $1 \mathrm{a}$ and RI $1 \mathrm{~b}$ [10]. RI $\alpha 1 \mathrm{a}$ and $1 \mathrm{~b}$ mRNAs have been identified in most tissues and are differentially regulated by cAMP [11-13]. In the case of RII, it has been shown that RII $\alpha$ in the human testis but no other tissues examined, is encoded with an alternative amino-terminal region [14]. No functional consequences of alternative splicing of RI and RII have been reported.

Several splice variants are transcribed from the $\mathrm{C} \alpha$ and the $C \beta$ genes (PRKCA and PRKCB) and include $C \alpha 1, C \alpha S, C \beta 1, C \beta 2, C \beta 3$ and $C \beta 4$, in addition to an unknown number of abc forms of the $C \beta 3$ and $C \beta 4$ variants [15-20]. The major differences between the various $\mathrm{C}$ subunits are introduced through alternative use of exon 1 in the PRKCB and PRKCA genes, respectively $[16,21,22]$. In the case of $C \alpha 1$ exon 1-1 encodes an

\section{C) Biomed Central}


$\mathrm{N}$-terminal stretch of 14 amino acids that have three sites that undergo co- and posttranslational modifications. At the very $\mathrm{N}$-terminus a Gly is located that undergoes myristoylation in vivo [23]. C-terminal to the Gly an Asn is located that is partly deamidated in vivo leading to $C \alpha 1-A s p 2$ and $C \alpha 1$-iso( $\beta$ )Asp2 [24]. The third modification is PKA-autophosphorylation at Ser10 [25-27]. In the case of $C \beta 2$, exon 1-2 encodes an $\mathrm{N}$-terminal stretch of 62 amino acids that does not harbor sites for any of the modifications identified in C $\alpha 1$. Instead, the $C \beta 2 \mathrm{~N}$-terminus contains a stretch of hydrophobic amino acids that form an amphiphatic $\alpha$-helix displayed as a hydrophobic surface [20]. C $\alpha 1$ and $C \beta 1$ are more than $90 \%$ identical at the amino acid level and are ubiquitously expressed. $\mathrm{C} \alpha \mathrm{S}$ has only been identified in sperm cells [28], C $\beta 2$ is predominantly expressed in lymphoid cells [29,30], and $C \beta 3$ and $C \beta 4$ and their abc variants are mainly expressed in neuronal tissues $[15,16]$.

It is assumed that any known $\mathrm{C}$ subunit may associate with RI and RII to form PKAI and PKAII, respectively [9]. This has raised the question of the biological significance of PKAI and II holoenzymes containing various $\mathrm{C}$ isoforms within the same cell. Whereas no reports have been published on the functional consequences of holoenzymes formed with various $C$ subunits, it has been demonstrated that several cell types expressing RI $\alpha$ are highly proliferative and may also be associated with malignancy [31-34]. Using a genetic approach it has also been demonstrated that constitutive ablation of RI $\alpha$ but not RI $\beta$ is prenatal lethal whereas ablation of the RII variants results in more discrete defects, affecting differentiation of adipose tissue and neural functions [35-37]. The levels of RI and RII as well as tissue- and subcellular expression varies. They also show differential affinities for A-kinase anchoring proteins (AKAP). Furthermore, when determining the structure of the PKA holoenzymes it was found that RI and RII contact the substrate binding site of the $C$ subunit either as a true PKA substrate (RII) or as a pseudosubstrate (RI) due to autophosphorylation of RII but not RI at Ser95 $[38,39]$. Despite these differences an explanation for biological differences at the cellular level between RI and RII are not fully appreciated [40,41]. However, it should be noted that RII autophosphorylation modulates AKAP-RII interaction in cardiac cells, leading to altered down-stream substrate phosphorylation and $\mathrm{Ca}^{2+}$ dynamics [42].

To investigate biological differences between RI and RII and to demonstrate if such differences are dependent on $\mathrm{C}$ subunit identity we formed PKAI and PKAII by co-transfecting $293 \mathrm{~T}$ cells with either RI $\alpha$ or RII $\alpha$ together with $C \alpha 1$ and $C \beta 2$, respectively. This demonstrated that PKAI was superior to PKAII in activating a
cAMP responsive element regardless of whether the holoenzyme contained $C \alpha 1$ or $C \beta 2$. Our results contribute to understand the functional significance of two PKA holoenzymes but not various $C$ subunits expressed in the same cell.

\section{Results}

To test for differential roles of PKAI and PKAII expressed in one cell we tested if markedly different $C$ subunits released from RI and RII are equally effective in regulating in vivo substrate phosphorylation. We chose the cell line $293 \mathrm{~T}$ as a model system since they express RI $\alpha$ and RII $\alpha$ associated with C $\alpha 1$ (Figure 1A, left panel), and not RI $\beta$ and RII $\beta$ (Figure 1A, right panel). In these cells PKAI and PKAII are distinctly located to the cytosol and Golgi-centrosomal area, respectively as demonstrated by immunostaining using anti-RI $\alpha$ (red) or anti-RII $\alpha$ (green) (Figure 1B). Co-immunostaining with anti-C demonstrated that $\mathrm{C} \alpha 1$ localization corresponded to $\mathrm{R}$ subunit localization. We also observed a weak nuclear staining of the $C$ subunit in the absence of cAMP (Figure 1C), whereas in the presence of the cAMP analogue, 8-CPT-cAMP $(340 \mu \mathrm{M})$ an increase in nuclear staining was observed (Figure 1C). We concluded that the 293T cells represented a suitable model system to study isoform differences between PKAI and PKAII formed with different $\mathrm{C}$ subunits.

To obtain 293T cells dominated by either PKAI or PKAII expression, we formed holoenzymes by transient transfection of plasmids over-expressing either RI $\alpha$ or RII $\alpha$ (pDeRI $\alpha$ or pExRII $\alpha$ ) in combination with either $\mathrm{C} \alpha 1$ or $\mathrm{C} \beta 2$ ( $\mathrm{pDeC} \alpha 1$ or $\mathrm{pDeC} \beta 2$ ). For some experiments the cells were also transfected with a vector expressing Luciferace controlled by a cAMP responsive element. $C$ subunit activity was tested in vitro using Kemptide as a substrate $[43,44]$; and in vivo using the Cre-Luciferase reporter system [45]. This revealed a dose-dependent increase in PKA-specific catalytic activity against Kemptide for both pDeC $\alpha 1$ and $\mathrm{pDeC} \beta 2$ with a maximum at $5600 \mathrm{ng}$ DNA (Figure 2A). The luciferase response was bell shaped and reached a maximum for pDeC $\alpha 1$ and pDeC $\beta 2$ at 1400 and 2800 ng DNA, respectively (Figure 2B). Next, we titrated the plasmids expressing RI and RII by transfecting 0-1280 ng of the plasmids pDeRI $\alpha$ and pExRII $\alpha$, respectively (Figure 2C, D).

Twenty four hours after transfection cells were lysed and $\mathrm{R}$ subunit levels were measured by immunoblotting and $\left[{ }^{3} \mathrm{H}\right]$-cAMP-binding. This revealed an increase in a $49 \mathrm{kDa}$ immunoreactive band as well as increased $\left[{ }^{3} \mathrm{H}\right]$ cAMP-binding that coincided with the amount of plasmid transfected (pDeRI $\alpha$, Figure $2 \mathrm{C}$ ). The same was the case when transfecting pExRII $\alpha$ (Figure 2D). Together this demonstrated a dose-dependent expression of both $\mathrm{RI} \alpha$ and RII $\alpha$. 


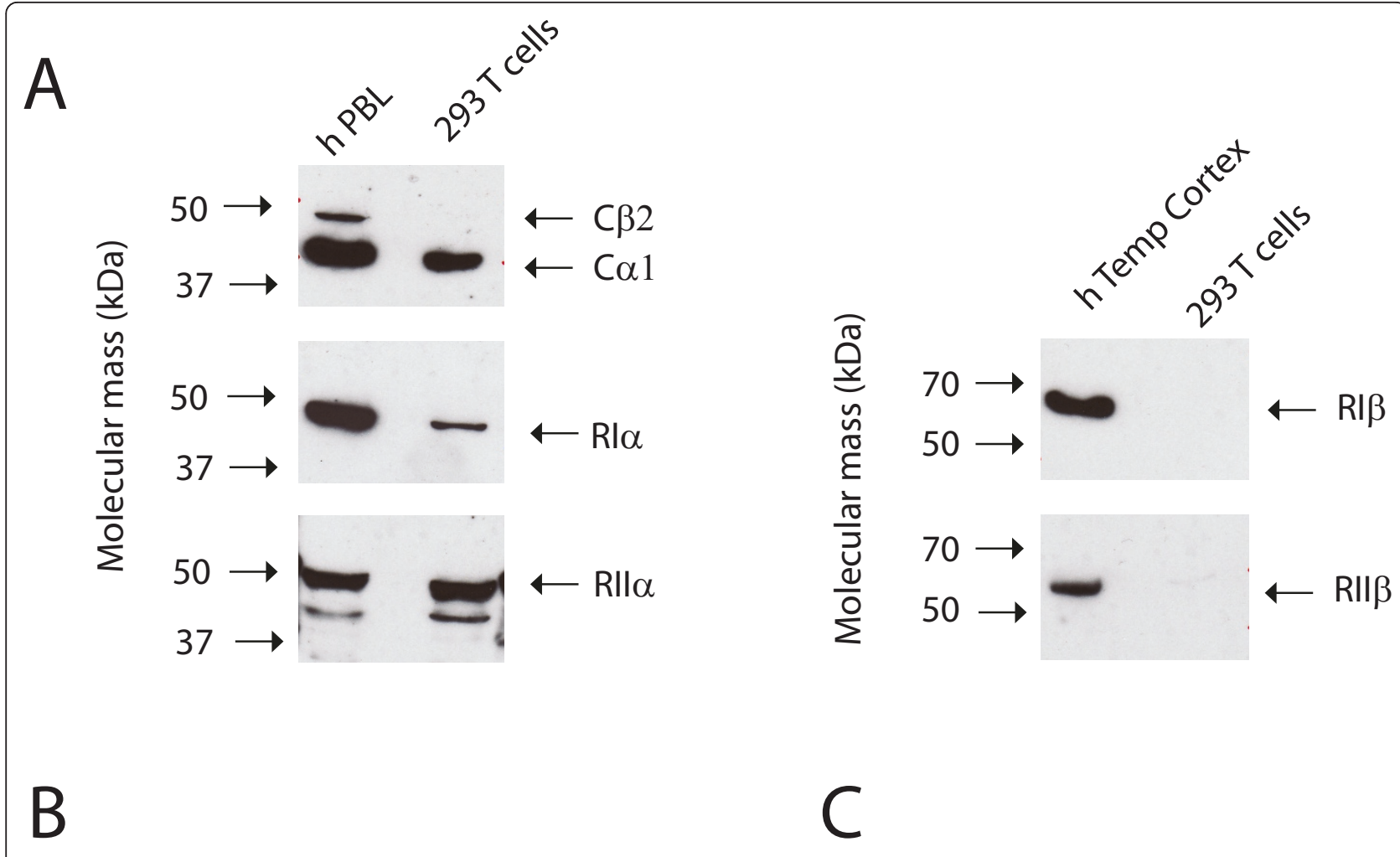

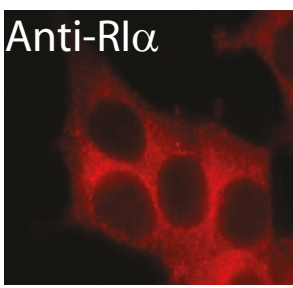
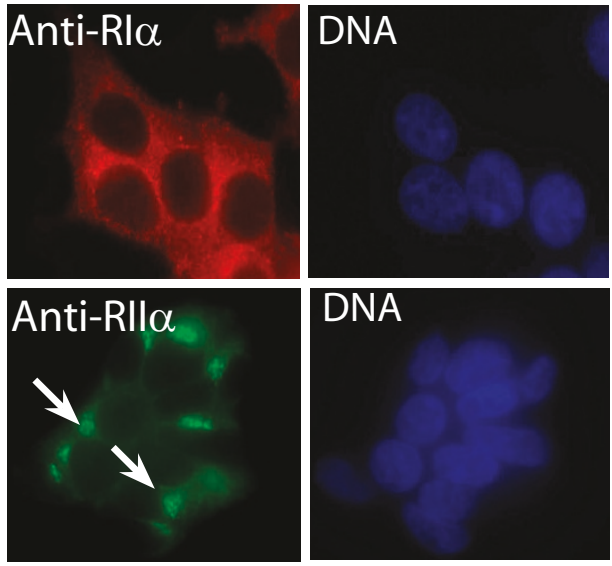
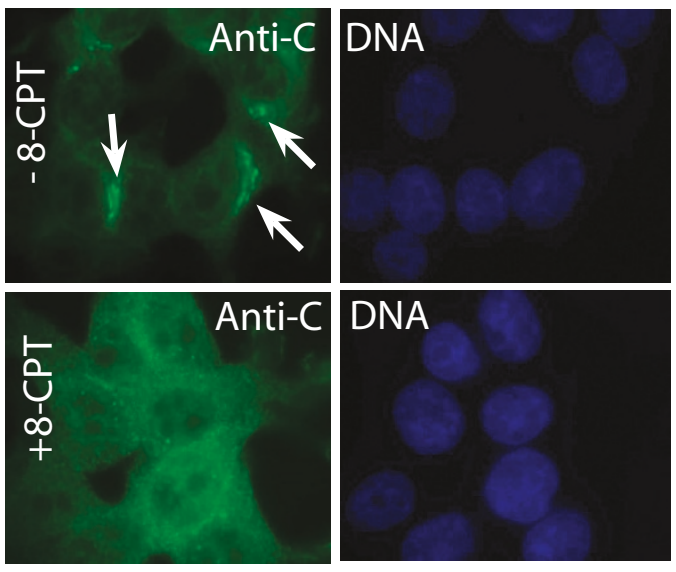

Figure 1 PKAI (Rl $\alpha C \alpha 1)$ and PKAll (RIl $\alpha C \alpha 1)$ are expressed in 293T cells. (A) Cell extracts of 293T cells (40 $\mu$ g protein/lane) were analyzed by immunoblotting using a pan-anti-C antibody (upper left panel) and anti-Rla and anti-Rllo (lower left panels). The levels and identities of 293T cell $C$ and $R$ subunit expression were compared to human peripheral blood lymphocytes (hPBL) revealing expression of C $\alpha$ 1, Rl $\alpha$ and Rll $\alpha$. No detectable levels of RI $\beta$ and RII $\beta$ were identified when compared to extracts of human temporal cortex (hTempCortex, right panels).

(B) Immunofluorescence analysis of PKA RI and RII in 293T cells. Rla (Anti-RI, red) is expressed diffusely in the cytosol and Rll $\alpha$ (Anti-RIl, green) is expressed in the Golgi-centrosomal area of 293 T cells. (C) Immunofluorescence analysis of PKA C subunits in 293T treated without (-) or with (+) $340 \mu \mathrm{M}$ 8-CPT-CAMP.

Based on these transfections and earlier experiments (results not shown), we next formed PKA holoenzymes by $\mathrm{R}$ and $\mathrm{C}$ co-transfections. We aimed at transfecting $\mathrm{R}$ plasmids to levels where $\mathrm{C}$ activity in the absence of cAMP were at basal levels, implying levels of $\mathrm{R}$ able to associate with all C subunits. 293T cells were co- transfected with a fixed amount of either $\mathrm{pDeC} \alpha 1$ (300 ng) or pDeC $\beta 2$ (1400 ng) together with increasing amounts of pDeRI $\alpha$ (0-1280 ng, Figure 3A, B) and pExRII (0-1280 ng, Figure 3C, D), respectively. Cell extracts were adjusted to $1 \mathrm{mg}$ total protein $/ \mathrm{mL}$ and total $\mathrm{C}$ subunit activity measured in the presence and 


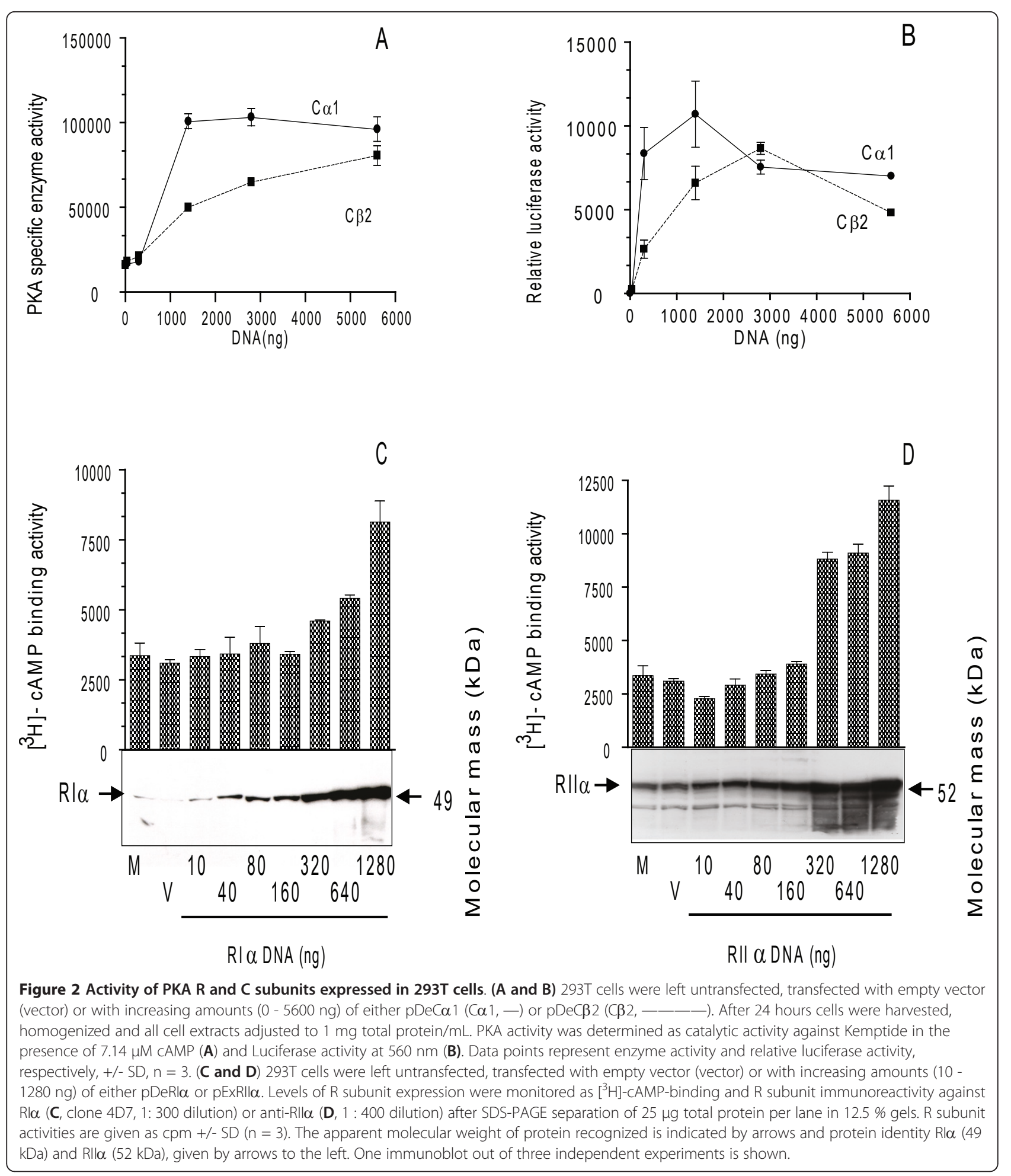

absence of $7.14 \mu \mathrm{M}$ cAMP. This demonstrated that C $\alpha 1-$ specific kinase activity was inhibited down to basal levels in the absence of cAMP at $640 \mathrm{ng}$ pDeRIa (Figure 3A), which was equal to $28 \pm 1.4 \mathrm{pmol} \mathrm{RI} \alpha / \mathrm{mg}$ total protein (Table 1 ). In the case of $C \beta 2$-specific activity it was down to basal levels in the absence of cAMP at $80 \mathrm{ng}$ pDeRIa (Figure 3B) which was equal to $11.8 \pm 2.7 \mathrm{pmol} \mathrm{RI} \alpha / \mathrm{mg}$

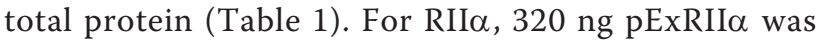
required for optimal C $\alpha 1$ inhibition (Figure 3C), which was equal to $16.2 \pm 0.5 \mathrm{pmol}$ RII $\alpha / \mathrm{mg}$ total protein 

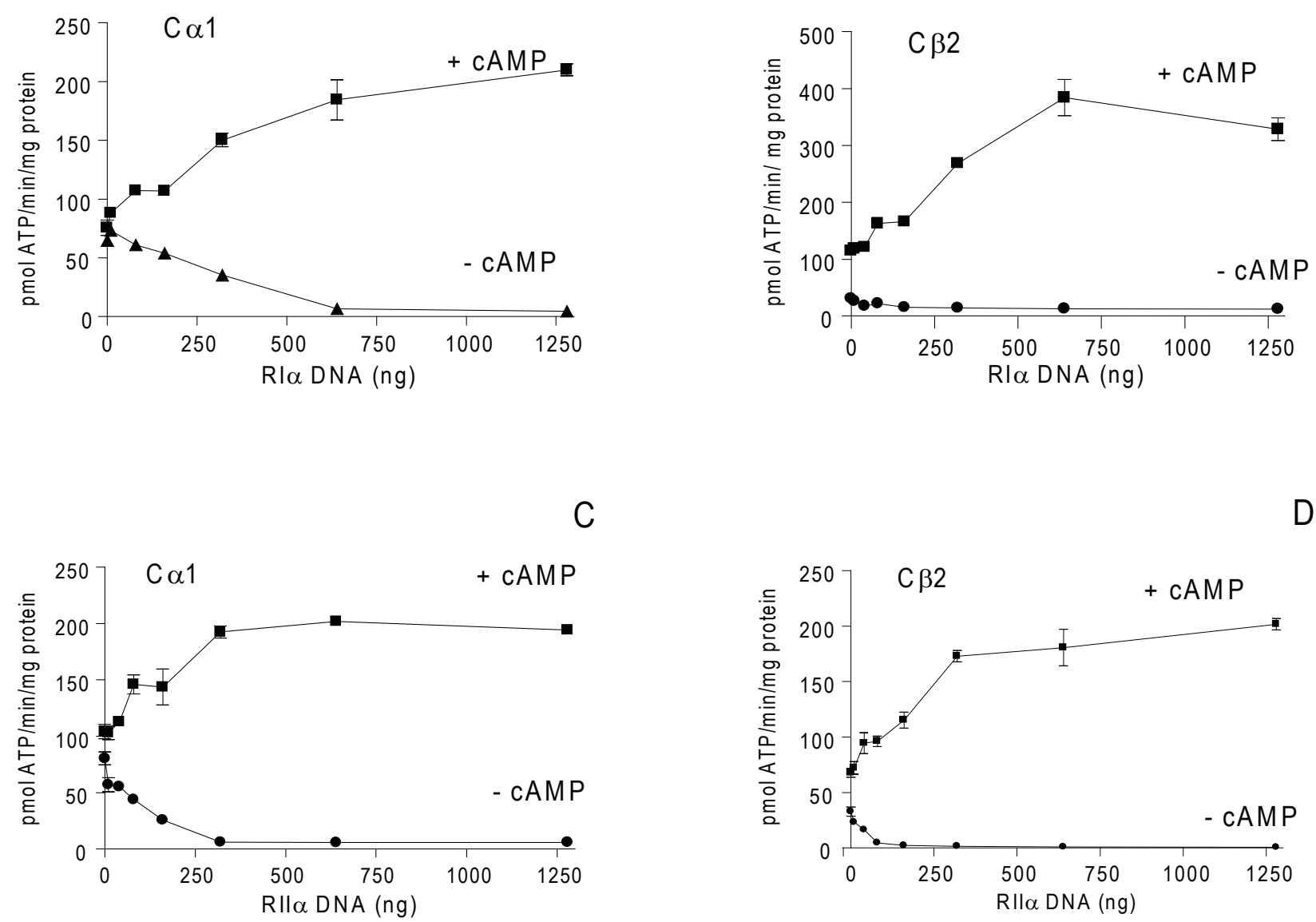

C

Figure 3 Expressed Rl $\alpha$ and Rll $\alpha$ inhibit expressed $C \alpha 1$ and $C \beta 2$ catalytic activity in a dose-dependent manner. 293T cells were cO-

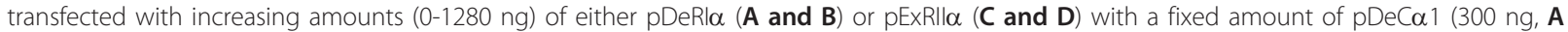
and C) or pDeC $\beta 2$ (1400 ng, B and D). Cells were harvested after 24 hours, cell extracts adjusted to $1 \mathrm{mg}$ total protein/mL and assayed for PKAspecific phosphotransferase activity in the presence (+ CAMP) and absence (- CAMP) of $7.14 \mu \mathrm{M}$ CAMP. Data points represent pmol ATP transferred/min/mg protein) +/- SD $(n=2-6)$.

(Table 1). Finally, $80 \mathrm{ng}$ pExRII $\alpha$ was required to inhibit $\mathrm{C} \beta 2$ activity to basal levels (Figure 3D) which was equal to $9.6 \pm 2 \mathrm{pmol}$ RII $\alpha / \mathrm{mg}$ total protein. In order to compare in vitro and in vivo PKA activity, protein extracts were analyzed against Kemptide phosphorylation and luciferace activity after transfection with CageCre-Luciferase (700 ng) together with either $300 \mathrm{ng}$ $\mathrm{pDeC} \alpha 1$ or $1400 \mathrm{ng} \mathrm{pDeC} \beta 2$ and increasing amounts of pDeRI $\alpha$ and pExRII $(160-1280$ ng DNA, Figure 4A-D). In these experiments psv- $\beta$-Galactosidase (1000 ng) was

Table 1 Concentrations of RI and RII required for maximal inhibition of transfected $C$ subunit

\begin{tabular}{lll}
\hline Subunits & C $\alpha 1$ (300 ng DNA) & C $\beta 2$ (1400 ng DNA) \\
\hline Rl $\alpha$ & $28 \pm 1.4^{*}$ & $11.8 \pm 2.7$ \\
Rll $\alpha$ & $16.2 \pm 0.5$ & $9.6 \pm 2$ \\
\hline
\end{tabular}

*Concentration of $\mathrm{R}$ subunit (pmol/mg protein) required for $100 \%$ inhibition of $C \alpha 1$ and $C \beta 2$ activity. used for normalization (see Methods). This showed that luciferase activity induced by $C \alpha 1$ and $C \beta 2$ was completely inhibited by both RI $\alpha$ and RII $\alpha$ at doses above or equal to $640 \mathrm{ng}$ plasmid DNA.

The experiments in Figures 3 and 4 depict that $C \beta 2$ activity is fully inhibited at lower amounts of $\mathrm{R}$ than $\mathrm{C} \alpha 1$ is. This may imply that $\mathrm{C} \alpha 1$ is enzymatically more active than $C \beta 2$ or simply that $C \beta 2$ is more unstable than $C \alpha 1$ in the absence of $\mathrm{R}$. A previous report shows that the $\mathrm{C}$ subunit in its free active form is more rapidly degraded than $\mathrm{C}$ complexed with the $\mathrm{R}$ subunit dimer [46]. To test if $C \alpha 1$ and $C \beta 2$ display differential stability, identical amounts of $C \alpha 1$ and $C \beta 2$ plasmids were transfected alone or with $1280 \mathrm{ng}$ of pDeRIa. This confirmed (Figure 5 bars 2 and 3) that in the absence of RI $\alpha$ total $C \beta 2$ activity is significantly (" $\mathrm{p}<0.05$ ) lower compared to $\mathrm{C} \alpha 1$. This was not the case when RIa was co-transfected with the two C subunits. In this case both $C \alpha 1$ and $C \beta 2$ activities were 


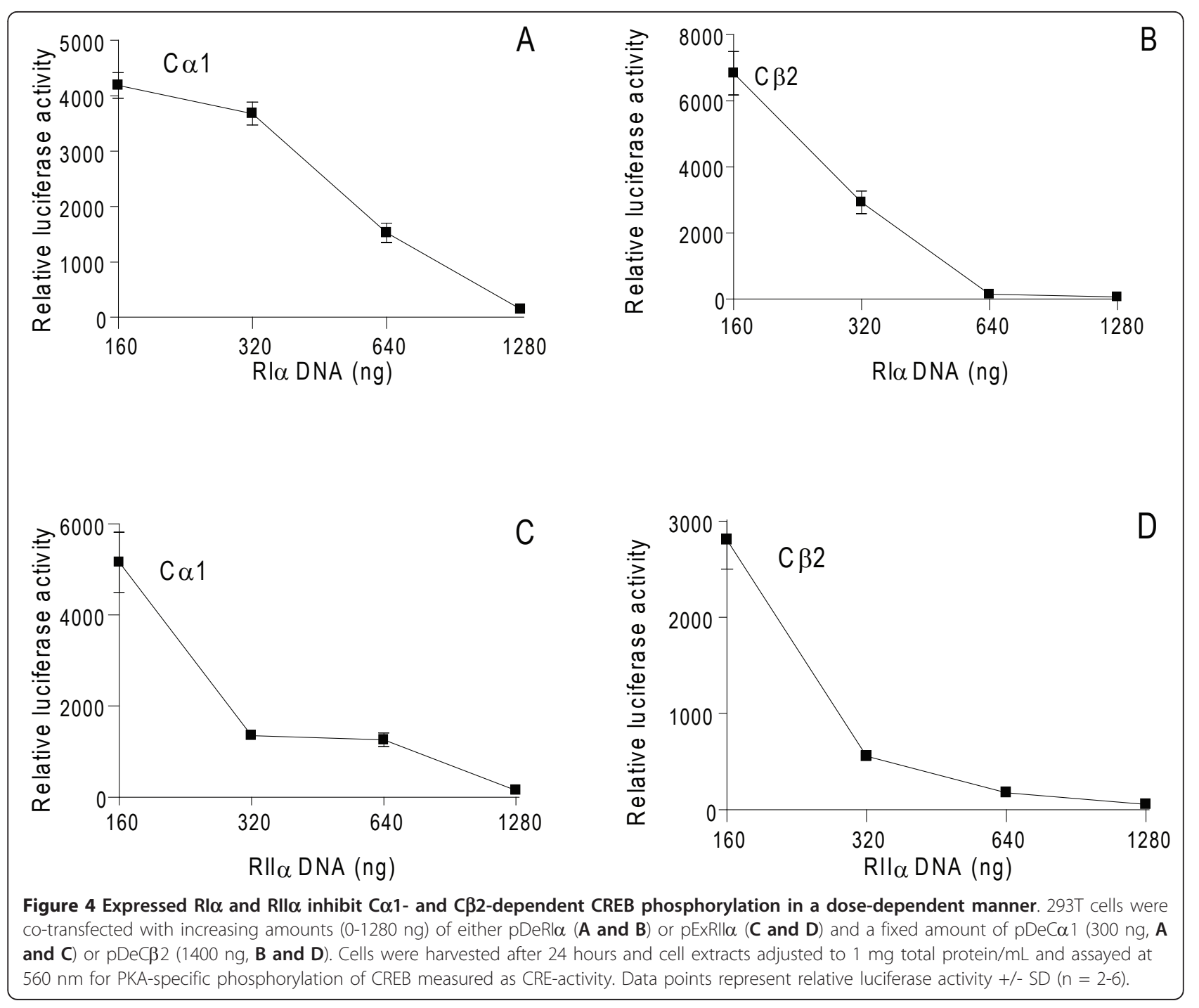

increased, however, to comparable levels after stimulation with cAMP (bars 5 and 7, ns). This demonstrated that RI $\alpha$ has a stabilizing effect on both $\mathrm{C}$ subunits. However the effect was more pronounced for $C \beta 2$ than $C \alpha 1$ indicating that $C \beta 2$ is more unstable than $C \alpha 1$ in the absence of $R$.

The results from Figures 3 and 4 demonstrated that we had obtained cell systems dominated by either PKAI or PKAII. Hence, the effects of PKAI and PKAII on in vitro (Kemptide) and in vivo (CREB) phosphorylation could be tested. For these experiments we used amounts of RI $\alpha$ and RII $\alpha$ required for complete inhibition of $\mathrm{C} \alpha 1$ and $C \beta 2$ respectively.

After 24 hours cell extracts were diluted to $1 \mathrm{mg}$ total protein $/ \mathrm{mL}$ and analyzed for cAMP dose-dependent induction of PKA kinase activity against Kemptide (Figure 6A, C). Both RI $\alpha$ and RII $\alpha$ were able to inhibit $\mathrm{C} \alpha 1$ and $C \beta 2$ kinase activity completely in the absence of cAMP. When increasing the concentrations of cAMP from 5 to $5000 \mathrm{nM}$, kinase activity was peaking, in the case of $\mathrm{C} \alpha 1$ at $100 \mathrm{nM}$ cAMP when co-expressed with RI $\alpha$ and between 500 and $5000 \mathrm{nM}$ when co-expressed with RII $\alpha$. In the case of $C \beta 2$, maximum activity was achieved at concentrations between 500 and $5000 \mathrm{nM}$ cAMP when co-expressed with both RI $\alpha$ and RII $\alpha$. We further analyzed $\mathrm{C}$ subunit activity in vivo by measuring luciferace activity. Activity was measured after stimulation of the transfected cells with increasing concentrations of 8-CPT-cAMP $(0-320 \mu \mathrm{M})$ for 1 hour prior to harvesting. We observed that activity associated with $\mathrm{C} \alpha 1$ and $\mathrm{C} \beta 2$ released from both $\mathrm{RI} \alpha$ and $\mathrm{RII} \alpha$ increased in a dose-dependent manner, reaching maximum between 160 and $320 \mu \mathrm{M} 8$-CPT-cAMP (Figure $6 \mathrm{~B}, \mathrm{D})$. However, a more than two fold higher activity was observed against CREB when $C \alpha 1$ and $C \beta 2$ were released from RI $\alpha$ than from RII $\alpha$. Together these results indicated that the ability of $\mathrm{C}$ to phosphorylate nuclear substrates in vivo at saturating concentrations of cAMP when associated with PKAII was lower than 


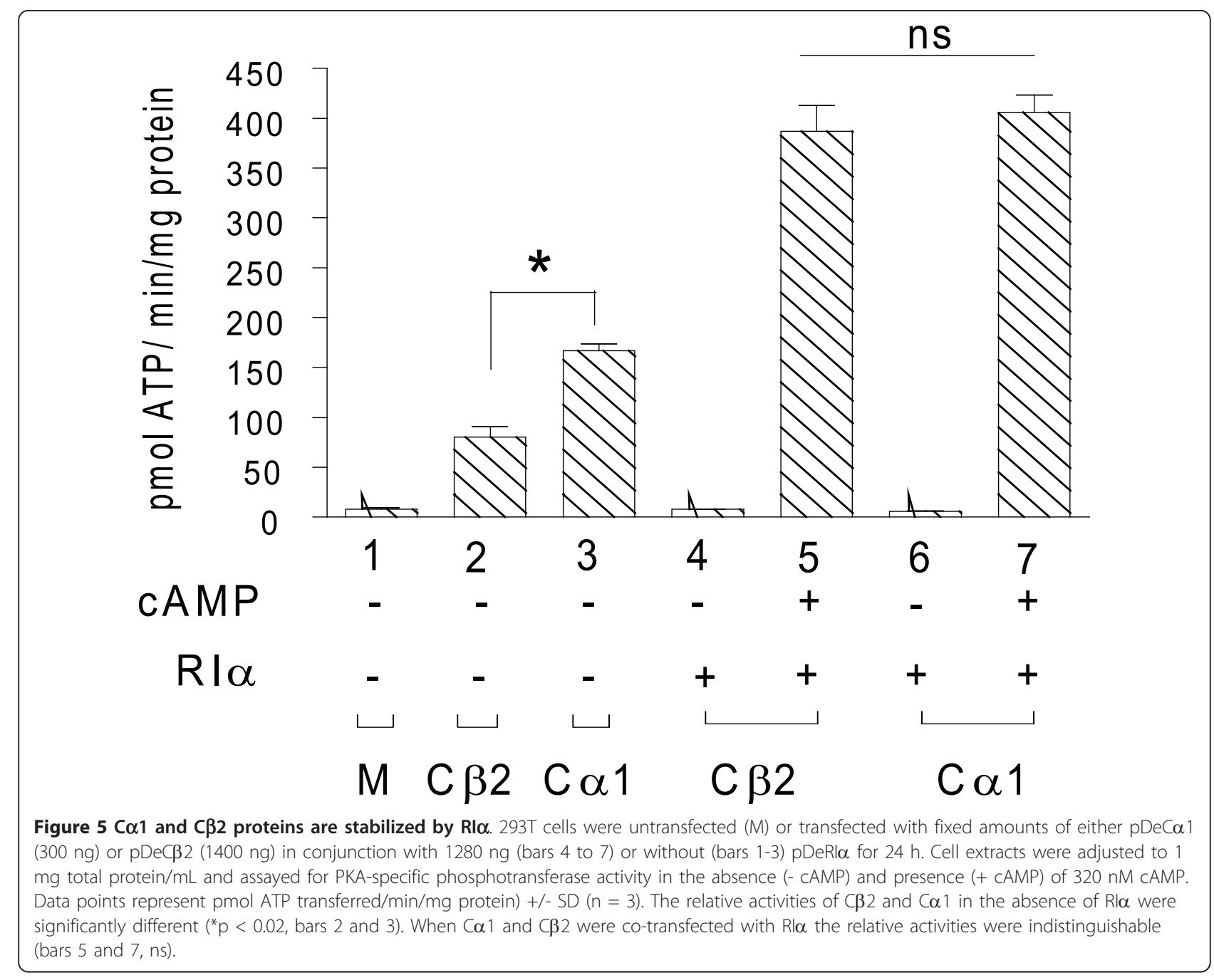

when associated with PKAI. This was apparent despite that total $\mathrm{C}$ subunit activity in vitro was comparable and protein concentrations were equal (Figure 6A to 6D). Since these results were seen regardless of $\mathrm{C}$ subunit isoform we suspected that the differences observed were associated with $\mathrm{R}$ subunit identity. To quantify the different efficacy of PKAI and PKAII to phosphorylate CREB in vivo, we therefore co-transfected pDeRI $\alpha$ (640 ng) and pExRII $\alpha$ (320 ng) with C $\alpha 1$ (300 ng pDeC $\alpha 1$ ) and monitored $\left[{ }^{3} \mathrm{H}\right]$-cAMP binding. This showed equal activities (Figure 7A) and hence comparable levels (Table 2) revealed as $22 \pm 1.5$ and $23 \pm 1.5$ pmol per mg total protein of $\mathrm{RI} \alpha$ and RII $\alpha$, respectively. We next determined $\mathrm{C}$ subunit activity in vitro after transfecting cells as described in Figure 7A, and in the absence (0 $\mathrm{nM}$ ) and presence of two concentrations of cAMP (5 and $5000 \mathrm{nM})$. This revealed basal activity in the absence, and low level activity in the presence of $5 \mathrm{nM}$ cAMP whereas 5000 nM cAMP resulted in comparable high levels of total $\mathrm{C}$ subunit activity released from both
PKAI and PKAII (Figure 7B). The $\mathrm{C}$ activities were equal to $25 \pm 1.4$ and $24.2 \pm 2.9$ pmol Cal per mg total protein for PKAI and PKAII, respectively (Table 2). This concluded that PKAI and PKAII were expressed at comparable levels under the present conditions. The latter was substantiated by a calculated $\mathrm{R}$ to $\mathrm{C}$ ratio close to 1 for both RI $\alpha$ versus $C \alpha 1$ (ratio 0.88) and RII $\alpha$ versus Ca1 (ratio 0.96, Table 2).

In lymphoid cells, it has been demonstrated that $\mathrm{R}$ subunits are more stable in the holoenzyme form compared to the free $\mathrm{R}$ subunit [47]. To test if the presence of $\mathrm{C} \alpha 1$ alone and in conjunction with cAMP would influence $R$ subunit levels we transfected 293T cells with either

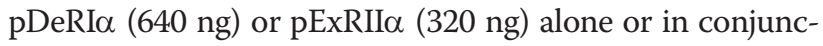
tion with pDeC $\alpha 1$ (300 ng). Transfected cells were treated without (0) or with incremental doses (1-320 $\mu \mathrm{M})$ of 8-CPT-cAMP for four hours before harvesting. Equal amounts of cell extracts (50 $\mu \mathrm{g}$ total protein per lane) were analyzed for proteins immunoreactive to anti-RI $\alpha$ and anti-RII $\alpha$, respectively. Figure 7C shows that 8-CPT-cAMP 


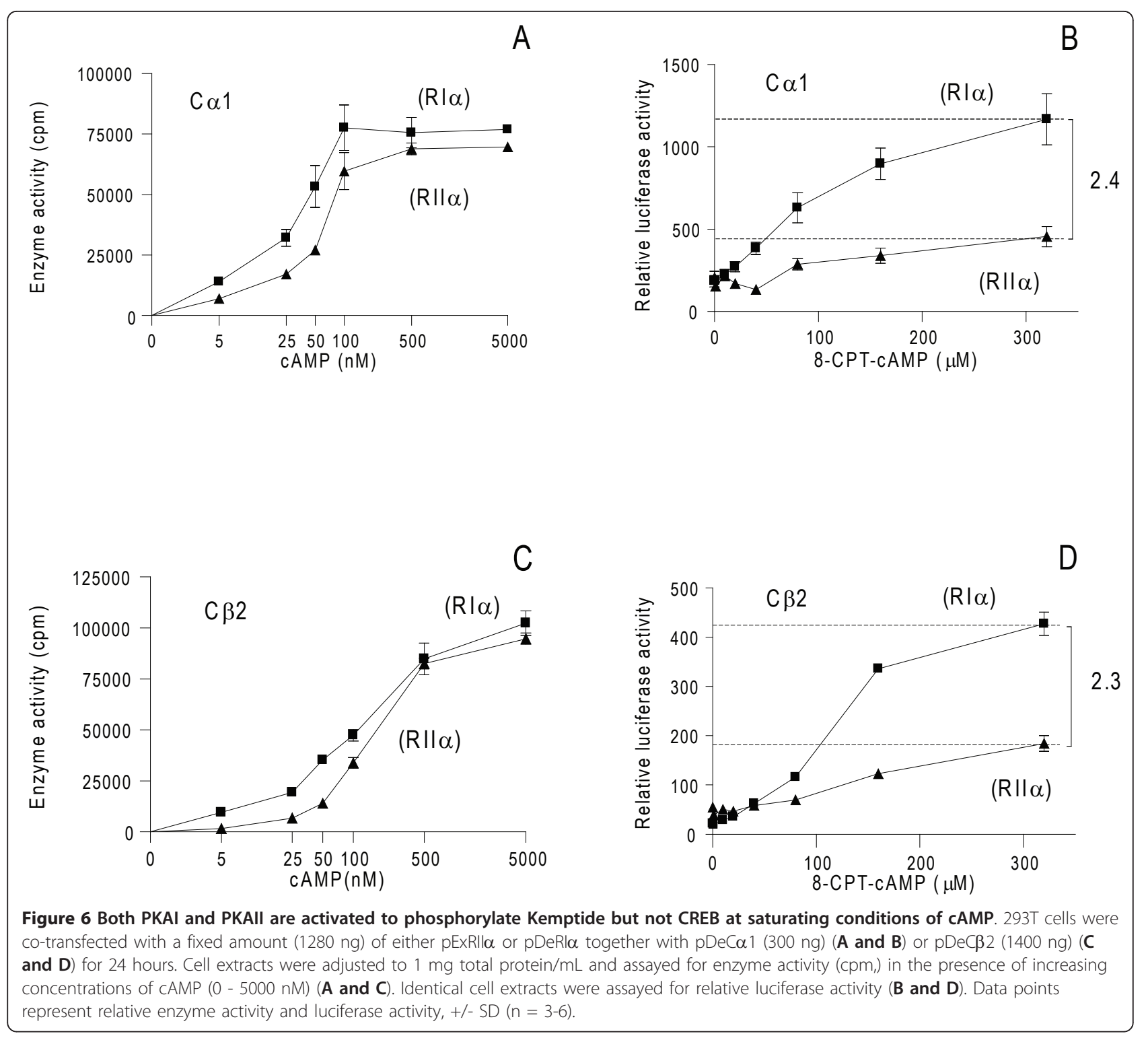

stimulation appeared not to influence $\mathrm{R}$ subunit levels and thus the cAMP sensitivity of the system.

Based on our observations (Figure 6B and 6D), we transfected cells as described in Figure $7 \mathrm{~B}$ with equal amounts of PKAI and PKAII and monitored luciferace activity after stimulation with two concentrations of 8CPT-cAMP ( 1 and $320 \mu \mathrm{M}$ ) for 1 hour before harvesting. As depicted in Figure 7D $320 \mu \mathrm{M}$ 8-CPT-cAMP induced more than a 13-fold increase in luciferace activity when associated with RI $\alpha$ compared to untreated cells. When associated with RII $\alpha$ the induction was 3fold. This difference was reflected in a relative induction of luciferace activity which was nearly twice as high for PKAI compared to PKAII (1.94 fold, $\mathrm{p}<0.01$ ).

\section{Discussion}

Despite that PKAI and PKAII are located to different areas when expressed in the same cell, it is believed that when dissociated by cAMP, the $\mathrm{C}$ subunits are all released to phosphorylate relevant substrates both in the cytosol and nucleus [48]. We formed PKAI and PKAII holoenzymes by co-transfecting $293 \mathrm{~T}$ cells with RI $\alpha$ or RII $\alpha$ together with either $C \alpha 1$ or $C \beta 2$.

We found that $\mathrm{C}$ subunits, irrespective of isoform, appeared more efficient in inducing Cre-luciferase when released from PKAI than PKAII.

To monitor total PKA activity in vitro and in vivo we applied cAMP and the cAMP analogue 8-CPT-cAMP. In vitro activation of PKA by cAMP was done to 
A

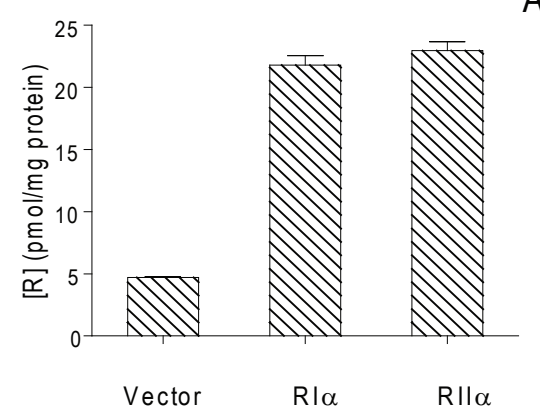

B
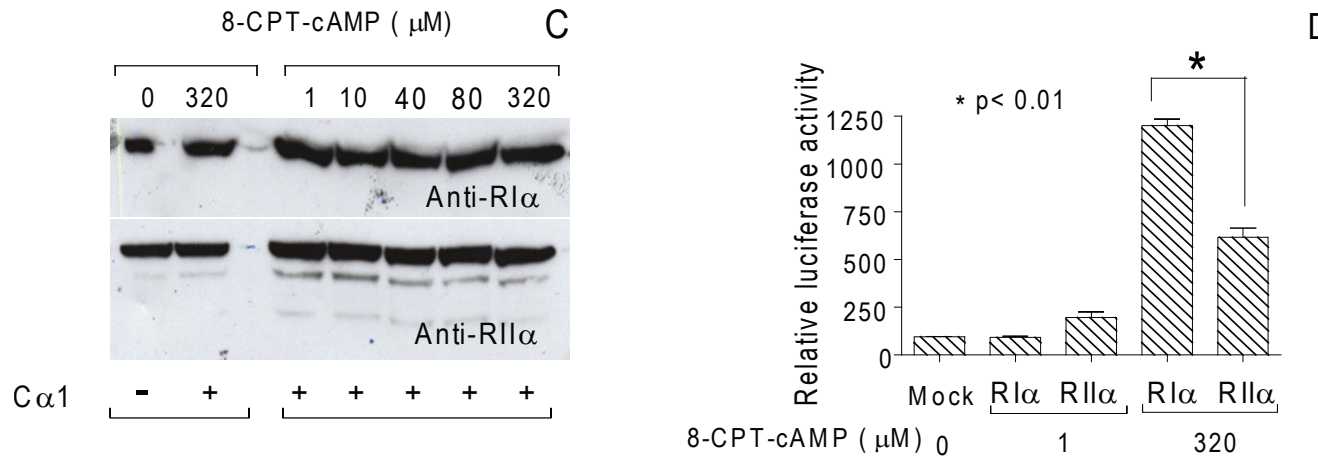

Figure 7 PKAll is less efficient compared to PKAl in regulating CRE activity in vivo. 293T cells were co-transfected with or without (empty

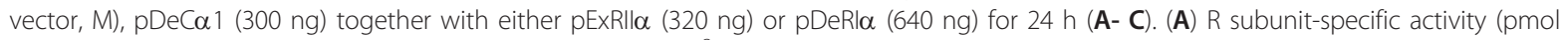
CAMP/mg protein) was monitored in the presence of $25 \mu \mathrm{M}\left[{ }^{3} \mathrm{H}\right]$-CAMP and showed comparable levels of Rl $\alpha$ and Rll . (B) Catalytic activity of C $\alpha 1$ was monitored in the absence (0) and presence of low $(5 \mathrm{nM})$ and high $(5000 \mathrm{nM})$ concentrations of cAMP. In the presence of $5000 \mathrm{nM}$ cAMP levels of transfected $C \alpha 1$ released from Rl $\alpha$ and Rll $\alpha$ were equal. (C) The stability of Rl $\alpha$ and Rll $\alpha$ was monitored in the presence (+) and absence (-) of $\mathrm{C} \alpha 1$ and the absence (0) and presence of incremental doses (1-320 $\mu \mathrm{M})$ of 8-CPT-CAMP. R subunit stability was determined according to immunoreactive R subunits after separation of cell extracts ( $25 \mu \mathrm{g}$ total protein) on SDS-PAGE (12.5 \% gels) and anti-Rla (1:300 dilution, upper panel) and anti-Rlla (1 : 400 dilution, lower panel). (D) 293T cells were left untreated (0) or stimulated for 1 hour with 8-CPTCAMP $(320 \mu \mathrm{M})$ before harvesting. Cell extracts were adjusted to $1 \mathrm{mg}$ total protein/mL and assayed for PKA-specific phosphorylation of CREB monitored as relative luciferase activity at $560 \mathrm{~nm}$. Data points represent relative luciferase activity +/- SD $(\mathrm{n}=2-6)$.

monitor if we had achieved comparable amounts of PKAI and PKAII in our experiments. For monitoring in vivo endogenous activity 8-CPT-cAMP was used because it has cell membrane permeable properties and is resistant to phosphodiesterase degradation [49]. The observation that cells transfected with PKAI induced higher levels of luciferace activity upon 8-CPT-cAMP stimulation than cells transfected with PKAII may have

Table 2 Ratios of transfected $R$ and $C$ subunits

\begin{tabular}{llll}
\hline PKA subunits & {$[\mathbf{R}]^{*}$} & {$[\mathbf{C}]$} & $\mathrm{R} / \mathrm{C}$ ratio \\
\hline Holoenzyme & & & \\
PKAl & $22 \pm 1.5$ & $25 \pm 1.4$ & 0.88 \\
PKAll & $23 \pm 1.5$ & $24 \pm 2.9$ & 0.96 \\
\hline
\end{tabular}

${ }^{*}$ Concentration of $\mathrm{R}$ and $\mathrm{C}$ subunit (pmol/mg protein) were determined at saturating concentrations of CAMP and assuming two CAMP binding sites per $R$ subunit and 600 pmol phosphate transferred by pure bovine $C$ per min per mg [65]. been due to relative affinities of the cAMP analogue. We consider this unlikely since 8-CPT-cAMP is a B-site selective cAMP analogue with higher affinity for RII than RI [49]. Further support for 8-CPT-cAMP as a competent activator of PKAII in vivo is found in that the concentration of 8-CPT-cAMP used is capable of displacing the $\mathrm{C}$ subunit from the RII subunit interacting with the centrosome in vivo in U2OS cells [50]. Taken together we conclude that 8-CPT-cAMP is fully capable to activate PKAII and does not selectively activate PKAI, implying that PKAII is less potent compared with PKAI in inducing Cre-luciferase activity.

An explanation for the biological significance of the phenomenon observed may rely on several factors. Despite that $25 \%$ of PKA is undissociated even in the presence of saturating concentrations of cAMP [51] it may not account for the differences we observed since this is observed for both PKAI and PKAII. However, it 
has been demonstrated that CAMP-dissociated RII and $\mathrm{C}$ reassociate much faster and to a much greater extent than RI and C. In fact it has been suggested that $C$ does not really leave RII under physiological conditions due to a rapid reassociation [52]. Hence, incomplete dissociation of $\mathrm{C}$ subunit from RII even at saturating concentrations of cAMP could be a mechanism explaining the phenomena observed here. Moreover, the biological significance of differential effects of activating PKAI and PKAII independent of $C$ subunit identity may be multiple. Recently a paper by Di and co-workers [53] demonstrated that PKAI and PKAII define distinct intracellular signaling compartments. They demonstrated that PKAI and PKAII activity were regulated by distinct, spatially restricted cAMP signals generated in response to specific $G$ protein-coupled receptors and which were regulated by unique subsets of the cAMP degrading phosphodiesterases.

We observed that $\mathrm{C} \alpha 1$ was more active than $C \beta 2$ when expressed in non-holoenzyme form. This may suggest differential $K_{d}$ of $C \alpha 1$ and $C \beta 2$ against RI and RII. This suggestion was supported in that the amount of $R$ plasmid required for complete inhibition of $\mathrm{C} \alpha 1$ and $C \beta 2$, respectively, was higher for RI compared to RII regardless of $\mathrm{C}$ subunit identity (28 pmol RI $/ \mathrm{mg}$ protein and $15 \mathrm{pmol}$ RII $\alpha / \mathrm{mg}$ protein for C $\alpha 1$ versus $\sim 12 \mathrm{pmol} \mathrm{RI} \alpha / \mathrm{mg}$ protein and $\sim 10 \mathrm{pmol} \mathrm{RII \alpha} / \mathrm{mg}$ protein for $C \beta 2$ ). However, we also observed that $C \beta 2$, but not $\mathrm{C} \alpha 1$ activity was stabilized when co-transfecting with the $\mathrm{R}$ subunit implying that the differences observed is due to protein instability of the $C \beta 2$ subunit and not lower $K_{d}$ for the $R$ subunit.

The latter is supported by the observation that $\mathrm{R}$ and $\mathrm{C}$ dissociation by cAMP in vivo promotes degradation of $\mathrm{C}$ subunits through posttranslational mechanisms which may involve proteasome action [54]. Furthermore, it has been shown that $C \alpha 1$ and $C \beta 1$ have identical $K_{d}$ values for RI [55]. To what extent $C \beta 2$ is more sensitive to proteasome degradation than $\mathrm{C} \alpha 1$ is not known. It should however be noted that the marked differences between the $\mathrm{C} \alpha 1$ and $\mathrm{C} \beta 2$ at the $\mathrm{N}$-terminus has been implicated in $\mathrm{C}$ subunit stability. For $\mathrm{C} \alpha 1$ it has been demonstrated that the $\alpha$-helix and Trp 30 are vital moieties for C $\alpha 1$ stability. This correlates with the location of the $\mathrm{N}$-terminal at the cleft interface where it orients the C-helix in the small lobe and the activation loop in the large lobe so that these subdomains are aligned in a way that allows for correct configuration of residues at the active site [56]. Moreover, we did not demonstrate a relative difference in potency of $C \beta 2$ versus $C \alpha 1$ in inducing Cre-luciferase activity irrespective of association with RI $\alpha$ or RII $\alpha$. The latter may suggest that $C \alpha 1$ and $C \beta 2$ behave identically in regulating Cre-luciferase activities. Hence, we concluded that the differential effects of PKAI and PKAII on luciferase activity detected in the present work are associated with $\mathrm{R}$ subunit but not $C$ subunit. The latter was unexpected since it has been speculated if the marked sequence differences at the $\mathrm{N}$-terminus will influence PKA holoenzyme features as such as localization. The latter has previously been demonstrated in that the $\mathrm{N}$-terminus of $\mathrm{C} \alpha 1$ is implicated in subcellular anchoring to A-kinase interacting protein 1 (AKIP1) [57]. Furthermore, at the N-terminal end the myristoyl moiety, which binds to a hydrophobic pocket on the surface of the large lobe when $C \alpha 1$ subunit is in the holoenzyme form [58,59], is exposed to the surroundings upon binding to RII. This makes the holoenzyme more hydrophobic [60]. In addition, whereas the N-terminal Asn moiety, is involved in fine-tuning of the enzyme distribution within the cell in vivo [61], Ser10 phosphorylation is known to introduce electro statically mediated forces which may help $C$ to remain soluble even when myristoylated [62-64]. Together this implies the N-terminal of $\mathrm{C} \alpha 1$ to contribute to regulation and tuning of subcellular targeting. Despite lack of experimental evidence the N-terminal amphiphatic $\alpha$-helix in $C \beta 2$ has been proposed to function as a targeting domain for $C \beta 2$ in vivo [20]. Despite the obvious differences between $C \alpha 1$ and $C \beta 2$ we did not observe any experimental evidence on the $\mathrm{C}$ subunits contributing to understand the differential effects of PKAI and PKAII.

In perspective, the various reports referred to here [51-53] together with our observations demonstrate differential activities and regulation by PKAI and PKAII which may add to understand the biological significance of two PKA holoenzymes expressed in one cell.

\section{Conclusions}

This study is important because it points to how tissuedependent expression of genes encoding subunits of PKA achieve specificity in the cAMP signaling pathway. Our work shows that transfected PKAI holoenzymes are more efficient than PKAII in phosphorylating CRE elements in vivo regardless of $\mathrm{C}$ subunit identity. Furthermore we show that $C \beta 2$ appear more stable in the presence of $\mathrm{R}$ subunit than $\mathrm{C} \alpha 1$.

\section{Methods}

\section{Cell culture}

293T HEK cells were maintained in RPMI medium 1640 (Sigma) containing 10\% (v/v) Fetal Bovine Serum (Sigma), 2 mM L-Glutamine (Sigma) 1\% Non-essential amino acids (Gibco), 1\% Na-Pyruvat (Gibco) and 1\% (v/v) Penicillin/Streptomycin (Sigma). The cells were subcultured three times weekly. Twenty hours before transfection $293 \mathrm{~T}$ cells were grown in 6 well plates from a population of $0.7 \times 10^{6}$ cells per well containing $1.5 \mathrm{~mL}$ RPMI medium without Penicillin/Streptomycin. Plates were kept at $37^{\circ} \mathrm{C}$ in a humidified atmosphere under $5 \% \mathrm{CO}_{2}$. 


\section{Generation and expression of PKA vectors}

pEF-DEST $51^{\mathrm{TM}}$ (Invitrogen) expression vectors encoding human regulatory and catalytic subunits $\mathrm{RI} \alpha, \mathrm{C} \alpha 1$ and $C \beta 2$ were created using Gateway LR Clonase Reaction ${ }^{\mathbb{B}}$ (Invitrogen) and transformed into Library ${ }^{\circledR}$ efficiency DH5 $\alpha^{\text {TMC} C o m p e t e n t ~ c e l l s ~(I n v i t r o g e n) . ~ P l a s m i d ~ p B l u e-~}$ script containing RII $\alpha$ encoding fragment was digested with Eag I (New England Biolabs), ligated using T4 Ligase (Promega) in plasmid pExchange 6A (Promega) previously digested with Not I (Promega), and transformed into Ultramax ${ }^{\circledR} \mathrm{DH} 5 \alpha^{\mathrm{TM}}$ Competent cells (Invitrogen). Plasmids expressing catalytic subunits $C \alpha 1$ or $C \beta 2$ or/and regulatory subunits RII $\alpha$ or RIa herby termed $\mathrm{pDeC} \alpha 1, \mathrm{pDeC} \beta 2$, pDeRI $\alpha$, and $\mathrm{pExRII} \alpha$ where transfected using Lipofectamine 2000 (Invitrogen). In order to facilitate a reporter system, plasmids expressing Luciferase reporter gene and $\beta$-Galactosidase as a normalization control was co-transfected with $\mathrm{R}$ subunit and/or $C$ subunit in constant amounts $(0.7 \mu$ g CageCre-Luciferase reporter vector and $1 \mu \mathrm{g}$ Psv- $\beta$-Galactosidase vector) in all wells except wells kept as "mock" controls. A vector without insert was used to keep the amount of plasmid DNA transfected constant. Cells were stimulated with 8-CPT-cAMP for 1 or 4 hours (specified in the text) before being harvested 24 hours post transfection.

\section{Immunoblot analysis}

Immuno blotting was performed as previously described [15]. Membranes were incubated with mouse monoclonal anti-RII $\beta$ (cat \# 610625, BD Transduction laboratories) at 1:250 dilution, polyclonal rabbit anti-RI $\beta$ (cat \# SC-907, Santa Cruz Biotechnology, Inc.), anti-RII (cat \# 612243, BD Transduction laboratories) at 1:400 dilution or mouse monoclonal anti-RI $\alpha$ (Clone 4D7, [65]) at 1:300 dilution. Immunoreactive proteins were detected with HRP-conjugated secondary antibodies (ICN Diagnostics) and SuperSignal ${ }^{\mathbb{B}}$ West Pico Chemiluminiscent (Pierce).

\section{Phosphotransferase assays}

PKA-specific catalytic activity was determined as described previously [66]. Molar amounts of $C$ subunit were determined assuming 600 pmol phosphate transferred per min per mg pure bovine $\mathrm{C}$.

\section{Luciferase assay}

Briefly, 24 hours post transfection cells were harvested, lysed by sonication, and samples adjusted to equal protein concentrations $(1 \mathrm{mg} / \mathrm{mL})$. Lysates were added appropriate buffer containing $270 \mu \mathrm{M}$ Coenzyme A (Boehringer), $530 \mu \mathrm{M}$ ATP (Boehringer), $470 \mu \mathrm{M}$ Luciferin (SynChem), and immediately placed in a Luminometer (TD20/20, Turner Designs). Luminosity was measured after $2 \mathrm{sec}-$ onds delay at $560 \mathrm{~nm}$ for 15 seconds with $20.1 \%$ of intensity. Samples in the high end of luminosity were used to create a standard curve to ensure measurement in the linear range.

\section{R-binding assay}

The level of R-subunits was determined by specific $\left[{ }^{3} \mathrm{H}\right]$ cAMP binding in homogenates from transfected $293 \mathrm{~T}$ cells as previously described [15]. Molar amounts of $\mathrm{R}$ subunits were calculated assuming two cAMP binding sites per R subunit.

\section{Indirect Immunofluorescence (IF)}

IF of $293 \mathrm{~T}$ cells were performed as previously described [67]. Antibodies against RI (Clone 4D7, [65]) and RII (cat \# 612243, BD Transduction laboratories) were diluted (see figure legend). The anti-C antibodies were rabbit polyclonal anti-C $\alpha$ 1:100 (cat \# sc 903, Santa Cruz Biotechnology, Santa Cruz, CA).

\section{Statistics}

Data are presented as means \pm s.e.m and were analyzed by unpaired two-tailed $t$ test or by one-way analysis. A value of $<0.05$ was considered statistically significant. All statistics were calculated by the Graphpad prism 5.02 program.

\section{List of abbreviations}

C: catalytic subunit; CREB: CAMP-responsive element binding protein; PKA: protein kinase $A$; R: regulatory subunit of PKA.

\section{Acknowledgements}

This work was supported by the Research Council of Norway, the Norwegian Cancer Society, the Novo Nordisk foundation and the Throne Holst foundation.

\section{Author details}

'Department of Nutrition, Institute for Basic Medical Sciences, University of Oslo, Sognsvannsveien 9, P.O. Box 1046 Blindern, N- 0316 OSLO, Norway. ${ }^{2}$ Department of Biochemistry, Institute for Basic Medical Sciences, University of Oslo, Sognsvannsveien 9, P.O. Box 1112 Blindern, N- 0317 OSLO, Norway. ${ }^{3}$ Department of Pathology, The Norwegian Radium Hospital, Oslo University Hospital, Ullernchausseen 70, N-0310 Oslo, Norway. ${ }^{4}$ Department of Oncology, Ullevål Hospital, Oslo University Hospital, Kirkeveien 166, P.O. Box 4950, Nydalen N-0424, OSLO, Norway.

\section{Authors' contributions}

ØS carried out most of the experiments, participated in the design of the study and in drafting the manuscript and preparing it for submission. ACVL participated in the experiments, provided technical assistance and contributed in criticizing the manuscript. AK performed indirect immunofluorescence experiments and contributed in criticizing the manuscript. SE participated in indirect immunofluorescence experiments and provided technical assistance. $S \varnothing$ conceived the design of the study, helped in its coordination and contributed in criticizing the manuscript. BSS conceived the design of the study, helped in its coordination and wrote the manuscript. All authors read and approved the final manuscript.

Received: 29 September 2010 Accepted: 8 February 2011

Published: 8 February 2011

\section{References}

1. Butcher RW, Ho RJ, Meng HC, Sutherland EW: Adenosine 3', $5^{\prime}$ monophosphate in biological materials. II. The measurement of adenosine $3^{\prime}, 5^{\prime}$-monophosphate in tissues and the role of the cyclic 
nucleotide in the lipolytic response of fat to epinephrine. $J$ Biol Chem 1965, 240:4515-4523.

2. Walsh DA, Perkins JP, Krebs EG: An adenosine 3',5'-monophosphatedependant protein kinase from rabbit skeletal muscle. J Biol Chem 1968, 243:3763-3765

3. Doskeland SO: Evidence that rabbit muscle protein kinase has two kinetically distinct binding sites for adenosine $3^{\prime} ; 5^{\prime}$-cyclic monophosphate. Biochem Biophys Res Commun 1978, 83:542-549.

4. Corbin JD, Keely SL, Park CR: The distribution and dissociation of cyclic adenosine $3^{\prime}: 5^{\prime}$-monophosphate-dependent protein kinases in adipose, cardiac, and other tissues. J Biol Chem 1975, 250:218-225.

5. Reimann EM, Brostrom CO, Corbin JD, King CA, Krebs EG: Separation of regulatory and catalytic subunits of the cyclic $3^{\prime}, 5^{\prime}$-adenosine monophosphate-dependent protein kinase(s) of rabbit skeletal muscle. Biochem Biophys Res Commun 1971, 42:187-194.

6. Maller JL, Kemp BE, Krebs EG: In vivo phosphorylation of a synthetic peptide substrate of cyclic AMP-dependent protein kinase. Proc Natl Acad Sci USA 1978, 75:248-251.

7. Montminy MR, Bilezikjian LM: Binding of a nuclear protein to the cyclicAMP response element of the somatostatin gene. Nature 1987 328:175-178

8. Yamamoto KK, Gonzalez GA, Biggs WH, Montminy MR: Phosphorylationinduced binding and transcriptional efficacy of nuclear factor CREB. Nature 1988, 334:494-498

9. Skalhegg BS, Tasken K: Specificity in the CAMP/PKA signaling pathway. Differential expression, regulation, and subcellular localization of subunits of PKA. Front Biosci 2000, 5:D678-D693.

10. Solberg R, Sandberg M, Natarajan V, Torjesen PA, Hansson V, Jahnsen T, Tasken K: The human gene for the regulatory subunit RI alpha of cyclic adenosine 3', 5'-monophosphate-dependent protein kinase: two distinct promoters provide differential regulation of alternately spliced messenger ribonucleic acids. Endocrinology 1997, 138:169-181.

11. Barradeau S, Imaizumi-Scherrer T, Weiss MC, Faust DM: Alternative 5'-exons of the mouse CAMP-dependent protein kinase subunit Rlalpha gene are conserved and expressed in both a ubiquitous and tissue-restricted fashion. FEBS Lett 2000, 476:272-276.

12. Dahle MK, Knutsen HK, Tasken KA, Pilz R, Tasken K: Cyclic AMP regulates expression of the RI alpha subunit of CAMP-dependent protein kinase through an alternatively spliced 5' UTR. Eur J Biochem 2001, 268:5920-5929.

13. Johansson CC, Dahle MK, Blomqvist SR, Gronning LM, Aandahl EM, Enerback S, Tasken K: A winged helix forkhead (FOXD2) tunes sensitivity to CAMP in T lymphocytes through regulation of cAMP-dependent protein kinase Rlalpha. J Biol Chem 2003, 278:17573-17579.

14. Oyen O, Myklebust F, Scott JD, Hansson V, Jahnsen T: Human testis cDNA for the regulatory subunit RII alpha of CAMP-dependent protein kinase encodes an alternate amino-terminal region. FEBS Lett 1989, 246:57-64.

15. Kvissel AK, Orstavik S, Oistad P, Rootwelt T, Jahnsen T, Skalhegg BS: Induction of Cbeta splice variants and formation of novel forms of protein kinase A type II holoenzymes during retinoic acid-induced differentiation of human NT2 cells. Cell Signal 2004, 16:577-587.

16. Orstavik S, Reinton N, Frengen E, Langeland BT, Jahnsen T, Skalhegg BS: Identification of novel splice variants of the human catalytic subunit Cbeta of cAMP-dependent protein kinase. Eur J Biochem 2001, 268:5066-5073.

17. Reinton N, Orstavik S, Haugen TB, Jahnsen T, Tasken K, Skalhegg BS: A novel isoform of human cyclic $3^{\prime}, 5^{\prime}$-adenosine monophosphatedependent protein kinase, c alpha-s, localizes to sperm midpiece. Biol Reprod 2000, 63:607-611.

18. Showers MO, Maurer RA: Cloning of CDNA for the catalytic subunit of cAMP-dependent protein kinase. Methods Enzymol 1988, 159:311-318.

19. Uhler MD, Carmichael DF, Lee DC, Chrivia JC, Krebs EG, McKnight GS: Isolation of CDNA clones coding for the catalytic subunit of mouse cAMP-dependent protein kinase. Proc Natl Acad Sci USA 1986, 83:1300-1304.

20. Wiemann $\mathrm{S}$, Kinzel V, Pyerin W: Isoform $\mathrm{C}$ beta 2 , an unusual form of the bovine catalytic subunit of CAMP-dependent protein kinase. J Biol Chem 1991, 266:5140-5146.

21. Desseyn JL, Burton KA, McKnight GS: Expression of a nonmyristylated variant of the catalytic subunit of protein kinase A during male germcell development. Proc Natl Acad Sci USA 2000, 97:6433-6438.
22. Guthrie CR, Skalhegg BS, McKnight GS: Two novel brain-specific splice variants of the murine Cbeta gene of CAMP-dependent protein kinase. J Biol Chem 1997, 272:29560-29565.

23. Carr SA, Biemann K, Shoji S, Parmelee DC, Titani K: n-Tetradecanoyl is the $\mathrm{NH} 2$-terminal blocking group of the catalytic subunit of cyclic AMPdependent protein kinase from bovine cardiac muscle. Proc Natl Acad SCl USA 1982, 79:6128-6131.

24. Jedrzejewski PT, Girod A, Tholey A, Konig N, Thullner S, Kinzel V, Bossemeyer D: A conserved deamidation site at Asn 2 in the catalytic subunit of mammalian CAMP-dependent protein kinase detected by capillary LC-MS and tandem mass spectrometry. Protein Sci 1998, 7:457-469

25. Herberg FW, Bell SM, Taylor SS: Expression of the catalytic subunit of cAMP-dependent protein kinase in Escherichia coli: multiple isozymes reflect different phosphorylation states. Protein Eng 1993, 6:771-777.

26. Toner-Webb J, van Patten SM, Walsh DA, Taylor SS: Autophosphorylation of the catalytic subunit of cAMP-dependent protein kinase. J Biol Chem 1992, 267:25174-25180

27. Yonemoto W, Garrod SM, Bell SM, Taylor SS: Identification of phosphorylation sites in the recombinant catalytic subunit of CAMPdependent protein kinase. J Biol Chem 1993, 268:18626-18632.

28. San Agustin JT, Leszyk JD, Nuwaysir LM, Witman GB: The catalytic subunit of the CAMP-dependent protein kinase of ovine sperm flagella has a unique amino-terminal sequence. J Biol Chem 1998 273:24874-24883.

29. Funderud A, Henanger $H H$, Hafte $\Pi$, Amieux PS, Orstavik S, Skalhegg BS: Identification, cloning and characterization of a novel $47 \mathrm{kDa}$ murine PKA C subunit homologous to human and bovine Cbeta2. BMC Biochem 2006, 7:20.

30. Orstavik S, Funderud A, Hafte TT, Eikvar S, Jahnsen T, Skalhegg BS: Identification and characterization of novel PKA holoenzymes in human T lymphocytes. FEBS J 2005, 272:1559-1567.

31. Fossberg TM, Doskeland SO, Ueland PM: Protein kinases in human renal cell carcinoma and renal cortex. A comparison of isozyme distribution and of responsiveness to adenosine 3':5'-cyclic monophosphate. Arch Biochem Biophys 1978, 189:272-281.

32. Goel S, Desai K, Bulgaru A, Fields A, Goldberg G, Agrawal S, Martin R, Grindel M, Mani S: A safety study of a mixed-backbone oligonucleotide (GEM231) targeting the type I regulatory subunit alpha of protein kinase A using a continuous infusion schedule in patients with refractory solid tumors. Clin Cancer Res 2003, 9:4069-4076.

33. Bradbury AW, Carter DC, Miller WR, Cho-Chung YS, Clair T: Protein kinase A (PK-A) regulatory subunit expression in colorectal cancer and related mucosa. Br J Cancer 1994, 69:738-742.

34. McDaid HM, Cairns MT, Atkinson RJ, McAleer S, Harkin DP, Gilmore P, Johnston PG: Increased expression of the Rlalpha subunit of the CAMPdependent protein kinase $A$ is associated with advanced stage ovarian cancer. Br J Cancer 1999, 79:933-939.

35. Amieux PS, McKnight GS: The essential role of RI alpha in the maintenance of regulated PKA activity. Ann N Y Acad Sci 2002, 968:75-95.

36. Kirschner LS, Kusewitt DF, Matyakhina L, Towns WH, Carney JA, Westphal H, Stratakis CA: A mouse model for the Carney complex tumor syndrome develops neoplasia in cyclic AMP-responsive tissues. Cancer Res 2005, 65:4506-4514.

37. Kirschner LS, Yin Z, Jones GN, Mahoney E: Mouse models of altered protein kinase A signaling. Endocr Relat Cancer 2009, 16:773-793.

38. Erlichman J, Rosenfeld R, Rosen OM: Phosphorylation of a cyclic adenosine $3^{\prime}: 5^{\prime}$-monophosphate-dependent protein kinase from bovine cardiac muscle. J Biol Chem 1974, 249:5000-5003.

39. Wu J, Brown SH, von DS, Taylor SS: PKA type llalpha holoenzyme reveals a combinatorial strategy for isoform diversity. Science 2007, 318:274-279.

40. Beene DL, Scott JD: A-kinase anchoring proteins take shape. Curr Opin Cell Biol 2007, 19:192-198

41. Tasken K, Aandahl EM: Localized effects of cAMP mediated by distinct routes of protein kinase A. Physiol Rev 2004, 84:137-167.

42. Manni S, Mauban JH, Ward CW, Bond M: Phosphorylation of the CAMPdependent protein kinase (PKA) regulatory subunit modulates PKAAKAP interaction, substrate phosphorylation, and calcium signaling in cardiac cells. J Biol Chem 2008, 283:24145-24154.

43. Witt JJ, Roskoski R Jr: Rapid protein kinase assay using phosphocellulosepaper absorption. Anal Biochem 1975, 66:253-258. 
44. Kemp BE, Graves DJ, Benjamini E, Krebs EG: Role of multiple basic residues in determining the substrate specificity of cyclic AMP-dependent protein kinase. J Biol Chem 1977, 252:4888-4894.

45. Mellon PL, Clegg CH, Correll LA, McKnight GS: Regulation of transcription by cyclic AMP-dependent protein kinase. Proc Natl Acad Sci USA 1989, 86:4887-4891

46. Alhanaty $\mathrm{E}$, Shaltiel S: Limited proteolysis of the catalytic subunit of CAMP-dependent protein kinase-a membranal regulatory device? Biochem Biophys Res Commun 1979, 89:323-332.

47. Skalhegg BS, Johansen AK, Levy FO, Andersson KB, Aandahl EM, Blomhoff HK, Hansson V, Tasken K: Isozymes of cyclic AMP-dependent protein kinases (PKA) in human lymphoid cell lines: levels of endogenous CAMP influence levels of PKA subunits and growth in lymphoid cell lines. J Cell Physiol 1998, 177:85-93.

48. Harootunian AT, Adams SR, Wen W, Meinkoth JL, Taylor SS, Tsien RY: Movement of the free catalytic subunit of CAMP-dependent protein kinase into and out of the nucleus can be explained by diffusion. Mol Biol Cell 1993, 4:993-1002.

49. Genieser HG, Winkler E, Butt E, Zorn M, Schulz S, Iwitzki F, Stormann R, Jastorff B, Doskeland SO, Ogreid D, et al: Derivatives of 1-beta-Dribofuranosylbenzimidazole $3^{\prime}, 5^{\prime}$-phosphate that mimic the actions of adenosine $3^{\prime}, 5^{\prime}$-phosphate (cAMP) and guanosine $3^{\prime}, 5^{\prime}$-phosphate (cGMP). Carbohydr Res 1992, 234:217-235.

50. Kvissel AK, Orstavik S, Eikvar S, Brede G, Jahnsen T, Collas P, Akusjarvi G, Skalhegg BS: Involvement of the catalytic subunit of protein kinase A and of HA95 in pre-mRNA splicing. Exp Cell Res 2007, 313:2795-2809.

51. Kopperud R, Christensen AE, Kjarland E, Viste K, Kleivdal H, Doskeland SO: Formation of inactive CAMP-saturated holoenzyme of CAMP-dependent protein kinase under physiological conditions. J Biol Chem 2002, 277:13443-13448.

52. Viste K, Kopperud RK, Christensen AE, Doskeland SO: Substrate enhances the sensitivity of type I protein kinase a to cAMP. J Biol Chem 2005, 280:13279-13284.

53. Di BG, Zoccarato A, Lissandron V, Terrin A, Li X, Houslay MD, Baillie GS, Zaccolo M: Protein kinase A type I and type II define distinct intracellular signaling compartments. Circ Res 2008, 103:836-844.

54. Boundy VA, Chen J, Nestler EJ: Regulation of CAMP-dependent protein kinase subunit expression in CATH.a and SH-SY5Y cells. J Pharmacol Exp Ther 1998, 286:1058-1065.

55. Cadd GG, Uhler MD, McKnight GS: Holoenzymes of CAMP-dependent protein kinase containing the neural form of type I regulatory subunit have an increased sensitivity to cyclic nucleotides. J Biol Chem 1990, 265:19502-19506.

56. Herberg FW, Zimmermann B, McGlone M, Taylor SS: Importance of the Ahelix of the catalytic subunit of CAMP-dependent protein kinase for stability and for orienting subdomains at the cleft interface. Protein Sci 1997, 6:569-579.

57. Sastri M, Barraclough DM, Carmichael PT, Taylor SS: A-kinase-interacting protein localizes protein kinase $A$ in the nucleus. Proc Natl Acad Sci USA 2005, 102:349-354

58. Bossemeyer D, Engh RA, Kinzel V, Ponstingl H, Huber R Phosphotransferase and substrate binding mechanism of the CAMPdependent protein kinase catalytic subunit from porcine heart as deduced from the 2.0 A structure of the complex with Mn2+ adenylyl imidodiphosphate and inhibitor peptide PKI(5-24). EMBO J 1993, 12:849-859.

59. Zheng J, Knighton DR, Xuong NH, Taylor SS, Sowadski JM, Ten Eyck LF: Crystal structures of the myristylated catalytic subunit of CAMPdependent protein kinase reveal open and closed conformations. Protein Sci 1993, 2:1559-1573.

60. Gangal M, Clifford T, Deich J, Cheng X, Taylor SS, Johnson DA: Mobilization of the A-kinase N-myristate through an isoform-specific intermolecular switch. Proc Natl Acad Sci USA 1999, 96:12394-12399.

61. Pepperkok R, Hotz-Wagenblatt A, Konig N, Girod A, Bossemeyer D, Kinzel V: Intracellular distribution of mammalian protein kinase A catalytic subunit altered by conserved Asn2 deamidation. J Cell Biol 2000, 148:715-726.

62. Hanakam F, Gerisch G, Lotz S, Alt T, Seelig A: Binding of hisactophilin I and II to lipid membranes is controlled by a pH-dependent myristoylhistidine switch. Biochemistry 1996, 35:11036-11044.
63. Hanakam F, Albrecht R, Eckerskorn C, Matzner M, Gerisch G: Myristoylated and non-myristoylated forms of the $\mathrm{pH}$ sensor protein hisactophilin II: intracellular shuttling to plasma membrane and nucleus monitored in real time by a fusion with green fluorescent protein. EMBO J 1996, 15:2935-2943

64. McLaughlin S, Aderem A: The myristoyl-electrostatic switch: a modulator of reversible protein-membrane interactions. Trends Biochem Sci 1995, 20:272-276.

65. Skalhegg BS, Landmark BF, Doskeland SO, Hansson V, Lea T, Jahnsen T: Cyclic AMP-dependent protein kinase type I mediates the inhibitory effects of $3^{\prime}, 5^{\prime}$-cyclic adenosine monophosphate on cell replication in human T lymphocytes. J Biol Chem 1992, 267:15707-15714.

66. Larsen ACV, Kvissel AK, Hafte T, Avellan CIA, Eikvar S, Rootwelt T, Orstavik S, Skalhegg BS: Inactive forms of the catalytic subunit of protein kinase $A$ are expressed in the brain of higher primates. Febs Journal 2008, 275:250-262

67. Kvissel AK, Orstavik S, Eikvar S, Brede G, Jahnsen T, Collas P, Akusjarvi G, Skalhegg BS: Involvement of the catalytic subunit of protein kinase A and of HA95 in pre-mRNA splicing. Exp Cell Res 2007, 313:2795-2809.

doi:10.1186/1471-2091-12-7

Cite this article as: Stakkestad et al.: Protein kinase A type I activates a CRE-element more efficiently than protein kinase A type II regardless of C subunit isoform. BMC Biochemistry 2011 12:7.

\section{Submit your next manuscript to BioMed Central and take full advantage of:}

- Convenient online submission

- Thorough peer review

- No space constraints or color figure charges

- Immediate publication on acceptance

- Inclusion in PubMed, CAS, Scopus and Google Scholar

- Research which is freely available for redistribution

Submit your manuscript at www.biomedcentral.com/submit
Ciomed Central 